\title{
Sistem Pendukung Keputusan Kinerja Dosen Menggunakan Metode Weighted Product (Studi Kasus : Fakultas Teknik Univesitas Islam Syekh-Yusuf Tangerang)
}

\author{
Syahriani Syam \\ Jurusan Teknik Informatika, Fakultas Teknik, Universitas Islam Syekh Yusuf, Jl. Mulana Yusuf No.10 Tangerang \\ Banten 15118, Indonesia \\ ssyam@unis.ac.id
}

\begin{abstract}
Abstrak.. Penelitian ini dilatar belakangi oleh beberapa persoalan yang berkaitan dengan belum optimalnya pelaksanaan penilaian kinerja dosen pada kegiatan belajar mengajar berdasarkan pendekatan logika Metode Weigh Product (WP) di Fakultas Teknik. Hal ini menjadi satu keprihatinan yang perlu disikapi dalam kompetensi pembelajaran, karena dapat berdampak terhadap rendahnya disiplin dan proses pembelajaran pada mahasiswa serta penilaian kenaikan pangkat dosen. Kegiatan penilaian kinerja dilakukan setiap tahun sebagai bagian dari proses pengembangan karir dan promosi dosen untuk kenaikan pangkat dan jabatan fungsionalnya. Proses penilaian yang dilakukan meliputi penilaian dosen oleh mahasiswa, kedisiplinan dosen terhadap memberi kuliah, alokasi waktu dalam mengajar, pendidikan terakhir, jabatan akademik serta karya ilmiah yang dihasilkan per priode oleh setiap dosen. Menggunakan Metode Weighted Product (WP) dapat membantu dalam pengambilan keputusan untuk menentukan penilaian kinerja dosen pada perguruan tinggi, serta proses penilaian kinerja dosen lebih efisien sehinga ketua jurusan lebih cepat mendapatkan informasi tentang kinerja dosen. Sistem pendukung keputusan yang memiliki database, dan penilaian kinerja dosen
\end{abstract}

Kata kunci: sistem pendukung keputusan, weight product, kinerja dosen, UNIS

\begin{abstract}
This research is based on several issues related to the unoptimal implementation of lecturer performance assessment on teaching and learning activities based on logical approach of Weigh Product Method (WP) in Faculty of Engineering. This becomes a concern that needs to be addressed in the competence of learning, because it can affect the low discipline and learning process on students and appraisal of lecturers. Performance assessment activities are conducted annually as part of the career development process and promotion of lecturers for promotion and functional positions. The assessment process includes the assessment of lecturers by students, lecturer's discipline to lecture, time allocation in teaching, last education, academic position and scientific work produced per priode by each lecturer. Using Weighted Product (WP) method can help in making decision to determine the performance of lecturer at university, and process of lecturer performance appraisal more efficient so that department chief get faster information about lecturer performance. Decision support systems that have databases, and lecturer performance appraisals
\end{abstract}

Keywords: decision support system, weighted product, lecturer performance, UNIS .

\section{Pendahuluan}

Dosen adalah pendidik profesional yang mempunyai tugas, fungsi, dan peran penting dalam mencerdaskan kehidupan bangsa. Dosen yang profesional diharapkan mampu berpartisipasi dalam pembangunan nasional untuk mewujudkan manusia Indonesia yang bertakwa kepada Tuhan Yang Maha Esa, unggul dalam ilmu pengetahuan dan teknologi, memiliki jiwa estetis, etis, berbudi pekerti luhur, dan berkepribadian.

Universitas Islam Syekh Yusuf (UNIS) merupakan salah satu perguruan tinggi di Tangerang, dimana proses penilaian setiap dosennya dilaksanakan setiap periode, yaitu setiap Semester. Proses penilaian yang dilakukan meliputi penilaian dosen melalui mahasiswa, kedisiplinan dosen terhadap memberi kuliah, alokasi waktu dalam mengajar, pendidikan terakhir, jabatan akademik serta karya ilmiah yang dihasilkan per periode oleh setiap dosen. Hasil dari penilaian kinerja ini akan menjadi bahan evaluasi guna meningkatkan kinerja dan setiap dosen yang terpilih sebagai dosen dengan kinerja terbaik akan diberikan penghargaan. Untuk membantu proses penilaian 


\section{Jurnal Keilmuan dan Aplikasi Teknik \\ UNISTEK, 2018, Edisi 5, No.1}

dibutuhkan sistem yang mampu mendukung keputusan penilaian kinerja dosen.

Berdasarkan observasi proses pengumpulan data dan pembersihan data penelitian menghasilkan jumlah dosen Fakultas Teknik Universitas Islam Syekh Yusuf Tangerang 60 0rang, terdiri dari 15 Dosen wanita, 25 Dosen laki-laki, 33 Dosen tetap di Fakultas Teknik, dan 27 Dosen luar biasa di Fakultas Teknik (Fakultas Teknik UNIS Tangerang, 2017).

Sistem Penunjang Keputusan adalah bagian dari sistem informasi berbasis komputer yang digunakan untuk mendukung pengambilan keputusan pada suatu organisasi atau perusahaan (Seen, 2013). Sistem pendukung keputusan digunakan untuk membantu pengambilan keputusan dalam situasi yang semi terstruktur dan situasi yang tidak terstruktur.

Metode Weighted Product (WP) adalah salah satu metode dalam sistem pengambilan keputusan dimana pengambilan sebuah keputusan dapat dilakukan secara lebih cepat dan tepat, sesuai kriteria yang di inginkan atau setidak nya mendekati kriteria yang di inginkan. Alternatif-alternatif pilihan yang diharapkan dapat memberikan daftar referensi kepada pembuat keputusan sebelum benar-benar mengambil suatu keputusan akhir (Putra, 2013).

Pengambilan keputusan dilakukan dengan pendekatan sistematis terhadap permasalahan melalui peroses pengumpulan keputusan data menjadi informasi serta ditambah faktor-faktor yang perlu dipertimbangkan dalam pengambilan keputusan. Pengambilan keputusan merupakan proses pemilihan aternative untuk mencapai tujuan atau sasaran tertentu (Rizal, 2013).

Pada penelitan sebelumnya tentang sistem pendukung keputusan penentuan bonus karyawan menggunakan Metode Weighted Product (WP) (Putra, 2013). Telah dilakukan pengembangan sistem pendukung keputusan dengan beberapa kriteria dan jumlah karyawan terbatas. Untuk itu dalam penelitian ini dibuat rancangan sistem pendukung keputusan yang mampu menangani penentuan kriteria yang tidak terbatas. Keputusan sudah menjadi hal yang biasa dalam kehidupan. Karena berhubungan dengan masalah dan solusi.

\section{Identifikasi Masalah}

Berdasarkan uraian latar belakang tersebut, maka dapat diidentifikasi permasalahan dari penelitian ini adalah sistem pengerjaan yang sudah ada masih menggunakan cara konvensional atau belum adanya aplikasi dengan database khusus, sehingga memungkinkan proses yang cukup lambat dalam hal melakukan penilaian maupun untuk pembuatan laporan

\section{Sistem Pendukung Keputusan (SPK)}

Pengambilan keputusan untuk menentukan prioritas produk unggulan daerah yang sesuai degan kebutuhan dan kemampuan diperlukan suatu keputusan yang akurat dan efektif agar tidak salah memilih dan meminimalisir kerugian baik dari segi biaya maupun waktu. Metode Weighted Porduct (WP) merupakan bagian dari konsep Multi Attibut Decision Making (MADM), dimana diperlukan normalisasi pada perhitungannya, karena intansi cukup memilih beberapa barang yang akan menjadi alternatif pemilihan dan memberikan nilai bobot pada perbandingan alternative dan kriterianya (Riza, 2011).

Keputusan sudah menjadi hal yang biasa dalam kehidupan. Karena berhubungan dengan masalah dan solusi. Definisi dari keputusan pada umumnya adalah pilihan (choice). Yaitu pilihan dari dua atau lebih kemungkinan. Jika berhubungan dengan proses, maka keputusan adalah keadaan akhir dari suatu proses yang lebih dinamisyang diberi label pengambilan keputusan. Keputusan dipandang sebagai proses karena terdiri dari suatu seri aktifitas yang berhubungan dan tidakan hanya dianggap sebagai tindakan yang bijaksana (Rizal, 2013).

\section{Metode Weighted Product (WP)}

Menurut Seen, (2013) Metode Weighted Product (WP) merupakan salah satu metode yang digunakan untuk menyelesaikan masalah. Metode Weighted Product (WP) menggunakan perkalian untuk menghubungkan nilai atribut (kriteria), dimana nilai setiap atribut harus dipangkatkan dulu dengan bobot atribut (kriteria) yang bersangkutan.

Metode Weighted Product (WP) memerlukan proses normalisasi karena metode ini mengalihkan hasil penilaian setiap atribut. Hasil perkalian tersebut belum bermakna jika dibandingkan (dibagi) dengan nilai standart. Bobot untuk atribut manfaat berfungsi sebagai pangkat positif dalam proses perkalian, sementara bobot biaya berfungsi sebagai pangkat negatif. Metode Weighted Product (WP) menggunakan perkalian sebagai untung menghubungkan rating atribut, dimana rating setiap atribut harus dipangkatkan dulu dengan bobot yang bersangkutan. Proses ini sama halnya dengan proses normalisasi (Putra,2013).

Dengan $\mathrm{i}=1,2, \ldots, \mathrm{m}$ dan $\mathrm{j}=1,2, \ldots \mathrm{n}$.

Keterangan:

$\Pi=$ Product

$\mathrm{Si}=$ Skor $/$ nilai dari setiap alternatif

$\mathrm{Xij}=$ Nilai alternatif ke- $\mathrm{i}$ terhadap atribut ke- $\mathrm{j}$

$\mathrm{Wj}=$ Bobot dari setiap atribut

Dimana (1) adalah pangkat bernilai positif untuk atribut keuntungan dan bernilai negatif untuk atribut biaya. Untuk perangkingan/ mencari alternatif yang terbaik dilakukan dengan rumus berikut:

- Penentuan nilai bobot W

$$
\begin{gathered}
\mathrm{Wj}=\mathrm{Wj} \\
\Sigma \mathrm{Wj}
\end{gathered}
$$

- Penentuan nilai Vektor S

$$
\mathrm{S}=(\text { WijAwj } . \mathrm{w}) .(\text { WinAwn } . w)
$$

- Penentuan nilai Vektor V 


$$
\mathrm{Vjn}=\mathrm{Si}
$$$$
\Sigma \mathrm{Si}
$$

Dimana :

$$
\mathrm{V}=\text { Preferensi alternatif dianalogikan sebagai }
$$
vektor V

$\mathrm{W}=$ Bobot kriteria / subkriteria

$\mathrm{j}=$ Kriteria

$\mathrm{i}=$ Alternatif

$\mathrm{n}=$ Banyaknya kriteria

$\mathrm{S}=$ Preferensi alternatif dianalogikan sebagai vektor S

Pada suatu perguruan tinggi sering kali mengalami kesulitan dalam menentukan kinerja dosen yang baik dikarena perhitungan yang dilakukan memakan waktu yang cukup lama dan terkadang terjadi kesalahan dalam perhitungan tersebut sehingga pengambilan keputusan dalam menentukan kinerja dosen menjadi lambat dan tidak akurat. Penentuan kinerja Dosen yang dilakukan pihak perguruan tinggi mencakup seluruh dosen yang mengajar di perguruan tinggi disetiap akhir semester. Berdasarkan permasalahan diatas maka dibutuhkan sebuah sistem pendukung pengambilan keputusan untuk menilai kinerja dosen. Sistem yang akan dibangun adalah sistem pendukung pengambilan keputusan kinerja dosen dengan menggunakan Metode Weighted Product (WP), maka ditetapkan beberapa kriteria diantaranya Pedagogik, Kepribadian, Sosial, Profesional.

Dengan Metode Weighted Product (WP) tidak perlu lagi dilakukan pembinaan oleh ketua jurusan, sedangkan dosen yang mempunyai nilai terendah akan dilakukan pembinaan oleh ketua jurusan dengan kriteria yang telah ditentukan. Dengan data-data yang ada penulis menerapkan Metode Weighted Product (WP). Untuk penyelesaiannya masalah diperlukan kriteriakriteria dan bobot dalam melakukan perhitungan sehingga akan dapat alternatif terbaik adalah sebagai berikut: Berikut adalah tabel penilaian kriteria:

Tabel 1. Kriteria

\begin{tabular}{clcc}
\hline \multirow{2}{*}{ Ro } & Ranah & \multicolumn{2}{c}{ Jumlah } \\
& Kompetensi & Kompetensi & Indikator \\
\hline 1 & Pedagogik & 7 & 45 \\
\hline 2 & Kepribadian & 3 & 18 \\
\hline 3 & Sosial & 2 & 6 \\
& & & \\
\hline 4 & Profesional & 2 & 9 \\
\hline & Total & 14 & 78 \\
\hline
\end{tabular}

\section{Metodologi}

Penelitian ini menggunakan metode Kuantitatif. Untuk mendapatkan data yang lebih mendalam dan lengkap, object yang akan di teliti dengan melakukan mengambil databas pada Fakultas Teknik Universitas Islam Syekh-Yusuf Tangerang.

- $\quad$ Penelitian Pendahuluan

Penelitian ini dilakukan untuk memperoleh kriteria-kriteria dalam penelitian, kriteria untuk
Mengetahui kelayakan calon mahasiswa baru untuk masuk pada Fakultas Teknik kemudian di buat Data input berupa Penilaian Dosen oleh Mahasiswa, Kedisiplinan Akademik, Pendidikan, Jabatan Akademik, Karya Ilmiah.

- Data Nilai

Setelah memperoleh kriteria-kriteria dari penelitian Pendahuluan selanjutnya akan di buat Data nilai Rata-rata

\section{Metode Pengumpulan Data}

Pengertian data menurut Nuzulla Agustina adalah keterangan mengenai sesuatu hal yang sudah sering terjadi dari himpunan fakta, angka, grafik, tabel, gambar, lambang, kata, huruf-huruf yang menyatakan sesuatu pemikiran, obyek, serta kondisi dan situasi. Zulkifli mengartikan data sebagai keterangan atau bukti mengenai suatu kenyataan yang masih mentah, masih berdiri-sendiri, belum diorganisasikan dan belum diolah. Sedangkan data menurut Wikipedia adalah catatan atas kumpulan fakta. Data merupakan jamak dari datum, berasal dari bahasa Latin yang berarti "sesuatu yang diberikan". Dalam penggunaan sehari-hari dari berarti suatu pernyataan yang diterima secara apa adanya. Pernyataan ini adalah hasil dari pengukuran atau pengamatan suatu variabel yang bentuknya dapat berupa angka, kata-kata, atau citra.

Penelitian yang dilakukan untuk menghasilkan data dan informasi yang diperlukan serta berhubungan dengan hal yang akan ditulis. Untuk mengumpulkan data serta informasi yang diperlukan oleh penulis menggunakan metode instrumen observasi penilaian kinerja guru yang disajikan pada tabel III-1 berupa data yang diperoleh dari hasil kegiatan penilaian kinerja guru yang sudah dilaksanakan.

Tabel 2. Instrumen Observasi Penilaian Kinerja Dosen

\begin{tabular}{clc}
\hline No. & \multicolumn{1}{c}{ Variabel Yang Diamati } & Kompetensi \\
\hline A. & Pedagogik & $\mathbf{7}$ \\
\hline 1. & $\begin{array}{l}\text { Menguasai karakteristik peserta } \\
\text { didik }\end{array}$ \\
\hline 2. & $\begin{array}{l}\text { Menguasasi teori belajar dan } \\
\text { prinsip-prinsip pembelajaran } \\
\text { yang mendidik }\end{array}$ \\
\hline 3. & Pengembangan kurikulum \\
\hline 4. & $\begin{array}{l}\text { Kegiatan pembelajaran yang } \\
\text { mendidik }\end{array}$ \\
\hline 5. & $\begin{array}{l}\text { Pengembangan potensi peserta } \\
\text { didik }\end{array}$ \\
\hline 6. & $\begin{array}{l}\text { Komunikasi dengan peserta } \\
\text { didik }\end{array}$ \\
\hline 7. & Penilaian dan evaluasi \\
\hline B. & Kepribadian \\
\hline 8. & $\begin{array}{l}\text { Bertindak sesuai dengan norma } \\
\text { agama, hukum, sosial, dan } \\
\text { kebudayaan nasional }\end{array}$ \\
\hline 9. & Menunjukkan pribadi yang \\
\hline
\end{tabular}




\begin{tabular}{ll}
\hline \multicolumn{1}{l}{ dewasa dan teladan } \\
\hline 10. & $\begin{array}{l}\text { Etos Kerja, tanggung jawab } \\
\text { yang tinggi, rasa bangga } \\
\text { menjadi guru }\end{array}$ \\
\hline C. & Sosial \\
\hline 11. & $\begin{array}{l}\text { Bersikap inklusif, bertindak } \\
\text { obyektif, serta tidak } \\
\text { diskriminatif. }\end{array}$ \\
\hline 12. & $\begin{array}{l}\text { Komunikasi dengan sesama } \\
\text { guru, tenaga kependidikan, } \\
\text { orang tua, peserta didik, dan } \\
\text { masyarakat. }\end{array}$ \\
\hline D. & Profesional \\
\hline 13. & $\begin{array}{l}\text { Penguasaan materi, struktur, } \\
\text { konsep, dan pola pikir keilmuan } \\
\text { yang mendukung mata } \\
\text { pelajaran yang diampu. }\end{array}$ \\
\hline $14 . \quad \begin{array}{l}\text { Mengembangkan } \\
\text { Keprofesionalan melalui } \\
\text { tindakan yang reflektif. }\end{array}$ \\
\hline
\end{tabular}

Implementasi

Langkah pertama yang harus dilakukan yaitu penginputan kriteria dan bobot awal, setelah itu di tentukan kriteria mana yang memiliki nilai keuntungan dan kriteria mana yang memiliki biaya, selanjutnya dilakukan perbaikan bobot yang bertujuan menormalisasi nilai dari setiap bobot. Langkah selanjutnya memasukan data dosen yang akan di lakukan penilaian serta di masukan nilai penilaian perkriteria yang sudah di tentukan. Setelah semua data di inputkan sistem akan menghitung penilaian kinerja dosen dan langsung menyeleksi berdasarkan peringkat tertinggi.

\section{Interface Aplikasi}

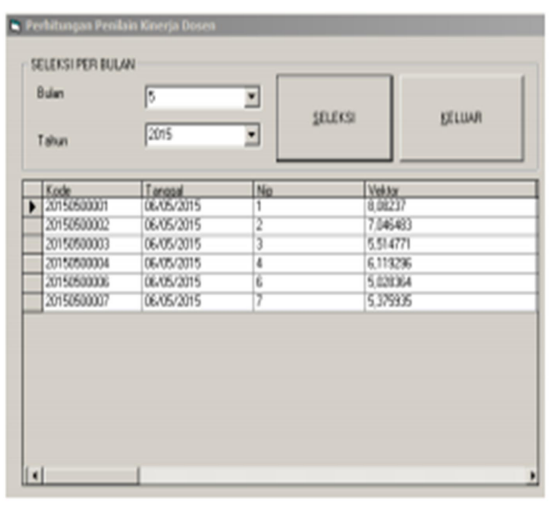

\section{Kesimpulan}

Dari hasil penelitian yang akan penulis lakukan maka dapat disimpulkan:

1. Prototipe sistem penilaian kinerja Dosen Fakultas Teknik UNIS Tangerang dikembangkan dengan pendekatan logika Weight Product (WP)

2. Prototipe sistem penilaian kinerja guru dengan sistem pendukung keputusan dengan pendekatan logika Weight Product (WP )lebih cepat dan mendekati akurat dari pada penentuan kinerja Dosen secara manual.

3. Prototipe sistem penilaian kinerja Dosen Fakultas Teknik UNIS Tangerang pendekatan logika Weight Product (WP ) menggunakan 14 kriteria dalam menentukan keputusan.

\section{Daftar Pustaka}

Al Fatta, H. (2007). Analisis dan Perancangan Sistem Informasi Untuk Keunggulan Bersaing Perusahaan dan Organisasi Modern, Yogyakarta: Andi Offset.

Basyaib. (2006). Sistem pendukung Keputusan Untuk Evaluasi Kinerja Dosen Dengan Metode $S A W$. Amik Amikom Cipta Darma Surakarta.

Indrajit. \& Eko,R. (2001). E-Commerce Kiat dan Strategi Bisnis di Dunia Maya Jakarta: PT. Elex Media Komputindo.

Jaya \& Putra. (2013). Sistem Pendukung Keputusan Penentuan Bonus Karyawan Menggunakan Metode Weighted Product (WP) (Studi Kasus: PT. Gunung Sari Medan). Jurnal Pelita Informatika Budi Darma, Volume : V, Nomor: 2.

Jogiyanto. (2005). Analisis dan Desain Sistem Informasi, Yogyakarta: Penerbit Andi.

Kusumadewi, Sri, Hartati, S., Harjoko A., \& Wardoyo, R., (2006) (Fuzzy Multi-Attribute Decision Making (Fuzzy MADM). Yogyakarta: PT. Graha Ilmu.

Marimi Wiji Astuti, (2011). Program Studi Sistem Informasi Sekolah Tinggi Manajemen Informatika \& Komputer Banjarbaru.

Mulyanto, (2009). Sistem Informasi dan Aplikasi, Yogyakarta: Pustaka Pelajar.

Purnomo H. (2010). Sistem pendukung keputusan kinerja karyawan menggunakan Metode Simple Additive Weighting (SAW) pada PT. Indonesia Steel Tube Work.

Raharjo, B. (2011). Belajar Otodidak Membuat Database MySQL Bandung: Informatika.

Riza, A. (2011). Perancangan Sistem Pendukung Keputusan Penentuan Prioritas Produk Unggulan Daerah Menggunakan Metode Weighted Product. Universitas Trunojoyo Madura.

Shelly, C. \& Vermaat. (2008). Discovering Computers: Menjelajah Komputer Fundamental Jakarta: Salemba Infotek.

Sianturi Ingot Seen, (2013). Sistem Pendukung Keputusan untuk Menentukan Pemilihan Jurusan Siswa dengan Menggunakan Metode Weighted Product (WP) (Studi Kasus: SMA SWASTA HKBP DOLOKSANGGUL). Jurnal nformasi dan Teknologi Ilmiah (INTI), Volume : I,Nomor : 1 .

Susanto, A. (2007). Sistem Informasi Manajemen, (Bandung: Lingga Jaya. 
Jurnal Keilmuan dan Aplikasi Teknik

UNISTEK, 2018, Edisi 5, No.1 